\title{
ADAPTING KNOWLEDGE MANAGEMENT STRATEGIES IN THE CONTEXT OF THE COVID-19 PANDEMIC. A PRELIMINARY OVERVIEW
}

\author{
Florina PINZARU ${ }^{a *}$, Alexandra ZBUCHEA ${ }^{b}$ \\ ${ }^{a, b}$ National University of Political Studies and Public Administration (SNSPA), Romania
}

\begin{abstract}
The impact of the Covid-19 pandemic on business is undoubtedly an ongoing debate, as it has led to the sudden closure of companies from a variety of sectors and to the disruptive transformation of many business models. Managers are navigating a broad range of issues affecting strategies and operations that are related to aspects such as coordinating remote teams, assuring the financial safety, reorganizing activities in the context of disrupted global supply chains, as well as adapting products and services to the reorientation of the customers' behavior. The Covid-19 pandemic has proved to be the most important test in the modern era in terms of adaptability, flexibility, and resilience of businesses: therefore, the learned lessons of this period should be registered, classified and integrated into knowledge management (KM) strategies. We present furthermore an opinion paper based on a semi-structured literature review, where the authors organize the most important aspects to be learned in business after the Covid-19 pandemic and propose a practical approach for transforming the specific information into knowledge assumed and valorized by managers.
\end{abstract}

KEYWORDS: knowledge management, Covid-19, business models, management.

\section{INTRODUCTION}

Since the outbreak of the Covid-19 pandemic, discussions on its impact on business have emerged in academia, press, and think tanks. At the moment of writing this paper, the first comprehensive studies on the topic are still to be realized. However, intuitively various authors have predicted a future impact of the Covid-19 pandemic not only at operational levels, but also on strategies and business models. Evidence of the influence of lockdown and disruptions on supply chains and organization of work have raised new interrogations on concepts that have become realities at large scale, such as the ones of agility and flexible resilience. Enterprises have been forced to adapt to the new pandemic conditions, sometimes by adopting faster ways in innovating and changing practices that could become sources for new business strategies and models.

In this opinion paper we examine the most important shifts that enterprises have affected as a direct result of the Covid-19 pandemic, in the attempt to organize them as lessons to be learned by managers. The most relevant aspects that we overview are the ones of the recovery of revenues, of the necessity to rebuild operations, to rethink organizations, to accelerate digitalization, to adapt marketing and to understand better stakeholders. We also discuss how these lessons should be translated from tacit knowledge to explicit knowledge in structured and organized knowledge management $(\mathrm{KM})$ strategies, considering practical elements as well as theoretical approaches useful in framing our proposal. Finally, we conclude by raising some questions for deeper thought and future research.

\footnotetext{
${ }^{*}$ Corresponding author. E-mail address: florina.pinzaru@facultateademanagement.ro.
} 


\section{IMPACT OF THE COVID-19 PANDEMIC ON BUSINESS}

\subsection{Businesses facing COVID-19 related challenges}

The COVID-19 pandemic has a complex impact on business, which can be structured on five main dimensions: recovering revenue, rebuilding operations, rethinking organization, accelerating digitalization, and adapted marketing (Pinzaru et al., 2020). Overcoming these challenges depends on leadership qualities (Sneader \& Sternfels, 2020) but also on organizational capabilities and abilities to manage knowledge, both tacit and explicit, both stored within the organization and spread across the external ecosystem.

Table 1. Lessons to be learned by managers after the Covid-19 pandemic

\begin{tabular}{|c|c|c|c|}
\hline & Dimension & Main aspects & Selected references \\
\hline 1 & $\begin{array}{l}\text { Recovering } \\
\text { revenues }\end{array}$ & $\begin{array}{c}\text { New supply chains or more efficient ones } \\
\text { More efficient and cost-effective } \\
\text { stock-keeping units/bar codes } \\
\text { More efficient and cost-effective } \\
\text { manufacturing processes } \\
\text { Rationalizing costs }\end{array}$ & $\begin{array}{c}\text { Jonasson et al., } 2020 \\
\text { Li et al., 2020 } \\
\text { Pató and Herczeg, } 2020 \\
\text { Paul and Chowdhury, } 2020 \\
\text { Shokrani et al., 2020 } \\
\text { Verma and Gustafsson, } 2020\end{array}$ \\
\hline 2 & $\begin{array}{l}\text { Rebuilding } \\
\text { operations }\end{array}$ & $\begin{array}{c}\text { Reorganizing supply chains and logistic } \\
\text { Modelling scenarios } \\
\text { Continuous learning }\end{array}$ & $\begin{array}{c}\text { Choi, } 2020 \\
\text { Finn et al., } 2020 \\
\text { Gupta et al., } 2020 \\
\text { KPMG, } 2020 \\
\end{array}$ \\
\hline 3 & $\begin{array}{l}\text { Rethinking } \\
\text { organizations }\end{array}$ & $\begin{array}{c}\text { Challenges related to remote working } \\
\text { Evolution of processes of collective } \\
\text { sensemaking }\end{array}$ & $\begin{array}{l}\text { Prasad et al., } 2020 \\
\text { Sethi and Brown, } 2020 \\
\text { Stephens et al., } 2020\end{array}$ \\
\hline 4 & $\begin{array}{l}\text { Accelerating } \\
\text { digitalization }\end{array}$ & $\begin{array}{c}\text { Freelance work } \\
\text { Remote teams } \\
\text { Literacy degree } \\
\text { Smart knowledge management }\end{array}$ & $\begin{array}{c}\text { Bartsch et al., } 2020 \\
\text { Mhlanga and Moloi, } 2020 \\
\text { Priyono et al., } 2020 \\
\text { Soto-Acosta, } 2020\end{array}$ \\
\hline 5 & $\begin{array}{l}\text { Adapting to } \\
\text { agile marketing } \\
\text { practices }\end{array}$ & $\begin{array}{l}\text { Changes in the customer behaviour } \\
\text { Cooperation of prosumers } \\
\text { Avoidance of clichés } \\
\text { Innovation } \\
\text { Brands with a mission }\end{array}$ & $\begin{array}{c}\text { Chesbrough, } 2020 \\
\text { Diebner et al., } 2020 \\
\text { Fuciu, } 2020 \\
\text { Heinonen and Strandvik, } 2020 \\
\text { Lang et al., } 2020 \\
\text { Sidibe, } 2020 \\
\end{array}$ \\
\hline
\end{tabular}

Source: adapted by authors

Recovering revenues is probably the most important aim of all types of businesses around the world. The drops in revenues were not only sudden but also prolonged in time considering the repeated waves of the pandemic. After the first ways of the pandemic, only $15 \%$ of CEOs worldwide felt confident about their companies' revenues and strength of processes and operations (PwC, 2020). A V-shaped recovery model was considered, while in the mid of the second wave of the pandemic fears of a $\mathrm{W}$-shaped recovery are the norm. The strategies adopted by companies in this context refer to new supply chains or more efficient ones through factors like localization, complexity reduction, and dual sourcing (Verma \& Gustafsson, 2020); more efficient and costeffective stock-keeping units/bar codes (SKUs) (Jonasson et al., 2020); more efficient and costeffective manufacturing processes (Li et al., 2020; Paul \& Chowdhury, 2020; Shokrani et al., 2020; Shen et al., 2020); rationalizing costs (Pató \& Herczeg, 2020). 
Fiscal recovery packages, as well as other governmental support schemes adopted by various countries as well as by the EU, are expected to leave a positive mark on the post-COVID-19 economies and businesses. Overcoming the health-related challenges, the public response will shift towards economic recovery and social healing, aims difficult to reach (Chinn et al., 2020). Access to knowledge and networks might lead to a competitive advantage in this framework.

Rebuilding operations could be a difficult and complex phenomenon, involving new operations and business models or significant redesign. Besides leadership capabilities facilitating this process, other necessary competencies to be considered are leveraging artificial intelligence and big data to establish a robust supply chain resiliency platform; incorporating tax optimization into the footprint analysis; embedding cost-to-serve as the foundational performance metric; getting the "makeversus-buy" mix right; driving purpose-fit inventory models: asset-light versus asset-heavy strategies; modelling scenarios; learning to hierarchize solutions and decisions - separating 'no regrets' from 'do later' (KPMG, 2020). Another dimension to consider is the logistics and the supply chain (Choi, 2020; Gupta et al., 2020). Effectively managing the logistics during and after the pandemic, aspects related to sanitary safety, technological fit, governmental regulation, financial and fiscal aspects, as well as human/psychological aspects have to be considered.

In times of increased uncertainty, such as the current pandemic, businesses need new management models, based on flexibility and continuous learning (Finn et al., 2020). In times of crisis, the traditional models do not cope effectively due to several reasons, such as reduced time for decisionmaking, fast evolutions, or informational instability. Organizational exhaustion and employee burnout are also part of the equation. In this framework, we observe that effective knowledge management helps in dealing with the above-presented challenges. One approach to achieve this goal would be experts and middle management autonomy to implement creative, yet pragmatic solutions (Mysore \& Usher, 2020). Nevertheless, this process is not simple since times of crises determine more aversion to risk-taking.

Rethinking organizations must consider the human dimension. One of the widest changes related to the COVID-19 pandemic is those related to the workforce. Cuts in wages, temporary or permanent termination of work contracts have been challenges for many businesses, of all types, faced worldwide (we possess more data from the US - see the studies of Brynjolfsson et al., 2020 or Papanikolaou \& Schmidt, 2020 -, but similar evolutions and concerns have been manifest in the EU and many countries - see some studies such as Fana et al., 2020; Pouliakas \& Branka, 2020, Rothwell, 2020, or the ILO Monitors and studies). Maybe the most difficult impact generated by the pandemic was on those with undeclared work positions, determining significant social disruptions with policy implications (Williams \& Kayaoglu, 2020). In this context, the work offer is higher than the demand. Still, businesses have to handle this situation with care, consider the troubled social climate, and tensed psychological ones. Another challenge for businesses is to design and ensure effective conditions for remote working. For many businesses, this has become the norm and it seems it will be part of business processes in the post-pandemic economy. Ensuring effective remote working conditions is not only a matter of logistics and technological capabilities but also has implications on work relations, soft skills valorisation, and psychological aspects. Companies need to be more digitally agile while ensuring the well-being of their staff. One of the PwC studies during the pandemic (Sethi \& Brown, 2020) shows that one of the main concerns of CEOs is the future of work, with its complex and various facets. Three-quarters of the CEOs have in mind the durable effects of the pandemic in this respect, considering that the changes taken to adapt to the new requirements and context will be adopted in the long-run. The study also found that almost two-thirds of the companies are concerned with their employees' wellbeing and psychological health, offering wellness programs. This approach is in line with studies documenting challenges related to remote working, such as loneliness, bad health habits, burnout, etc. (Prasad et al., 2020). Facing these new work dimensions involves managerial decisions regarding work processes, offering additional support by investing and employees' health and wellbeing, but also impact 
formally and informally the organizational culture. The way members of the organization communicate has changed, different processes of collective sensemaking have evolved (Stephens et al., 2020).

Digitalization is not a new phenomenon in business, but the COVID-29 pandemic accelerated this process. As Unruh and Kiron (2017) stated, digitalization is the process of the business model and processes innovation that exploits digital opportunities. COVID-19, by imposing remote working and asking for fast business adaptation and optimization, enhanced this process. We observe we are much closer to reaching the next level, of digital transformation. A study of McKinsey (2020b) shows that both organizations and industries have taken a quantum leap forward of several years in just several months. The view of top management on the role of technology changed dramatically during the pandemic compared to the previous years. If in 2017 almost half of the respondents considered that technology was primarily a means to cut costs, only $10 \%$ see it as a source of saving. The new role of technology consists of ensuring competitive advantage - for $38 \%$ (McKinsey, 2020b).

A crises-induced digital transformation might be observed in various domains associated with business and education, while variations among organizations in the same field will be observed depending on their digital capabilities, literacy, and financial flows (see for instance Mhlanga \& Moloi, 2020; Priyono et al., 2020; Soto-Acosta, 2020). Leadership and team cohesion are relevant factors supporting this process (Bartsch et al., 2020). Smart knowledge management might also be a factor differentiating between companies successful in digital transformation and those lagging.

Still, the actual impact of digital transformation on organizations is not fully understood and various scenarios are presented. For instance, it will affect the future of work, but the degree to which it will stimulate productivity, or freelance work is to be observed in the future (Soto-Acosta, 2020). At the core of these processes is how knowledge will be handled, and to what degree organizations will be willing to allow its free sharing. Other results will probably be the continuous development of new business models and patterns of competition. It is to consider that after the pandemic collaborative digital technologies will enabling real-time collaboration and knowledge sharing. Also, stakeholders will have increased and fast access to knowledge.

Agile marketing is the last dimension discussed. The past economic recession showed that businesses concerned with their customers' experiences thrived (Diebner et al., 2020). Therefore, responsive, responsible, and adequate marketing strategies lead to successful businesses in turbulent times. During the COVID-19 pandemic, this relationship seems to have been reconfirmed. Innovative marketing approaches proved successful. Considering the motivation and the level of collaboration, Wang, Hong, Li, and Gao (2020) developed a typology of marketing innovation strategies approached during the COVID-19 crisis. In all cases, marketing innovation strategies have a significant role in crisis management. One of the paths to success has been understanding the sudden orientation of customers towards essentials, entertainment, news consumption, and hobbies (PwC, 2020), as well as the new trends enhanced by the Covid-19 pandemic such as online buying, conscious consumption, health awareness and local buying (Accenture, 2020). Fast compliance with new needs and expectations, in the context of decreased buying power, might be crucial even for business survival. In terms of successful approaches, we mention the focus on innovation when possible (Heinonen \& Strandvik, 2020; Chesbrough, 2020). Heinonen and Strandvik (2020) document has imposed innovation by extreme disruptive changes in the environment, which is the base for renewal. Some short-term innovation might also occur, but the long-term ones are contributing to changing business models and marketing practices. These evolutions are influenced by the cooperation of prosumers (Lang et al., 2020). Probably during times of crises authentic value creation (Ratten, 2020), customer-centric design thinking (Yeon, 2020), and avoiding clichés in marketing communication (Fuciu, 2020) are even more relevant. Another appealing factor of differentiation during the pandemic has been the display of a mission-driven brand (Sidibe, 2020) since value and brand purpose are declared by consumers around the world as buying-decision factors (McKinsey, 2020a). 


\subsection{The growing importance of stakeholders in pandemic}

Freeman's popular definition of stakeholders as organizations, groups, or individuals „who can affect or is affected by the achievement of the organization's objectives" (Freeman, 1984, p.46) does not correspond so well to the evolution of theories and practices in the field of stakeholder management. Accountability to stakeholders has become increasingly more relevant (Berman \& Johnson-Cramer, 2019), while the empirical, practical, and ethical concerns of stakeholder management increased. Creating value for and engaging with stakeholders determines the sustainable development of an organization (Valentinov et al., 2019).

The studies developed during the COVID-19 pandemic show the enhanced relevance of the responsible behavior of business and consumers (Hunt et al., 2020). This sets a favorable framework for more active and demanding stakeholders. Having also in mind that even before the pandemic an increased distrust in businesses and even in the capitalist economic system has been documented (Jaeggi, 2016; Jappe, 2017), stakeholders could, even more, become active and with increased power over businesses. Therefore, more cooperation and more complex and strategic stakeholder management should be considered in the future. Businesses should consider lowering trust and increased expectations and aim for positive change, enhanced cooperation, and increased transparency. Part of this equation is knowledge transfer and open communication between all those involved.

Another aspect that highlights the increased importance of knowledge is the changing business ecosystem (Hunt et al., 2020). Capacity and community building should encompass at least the definitive stakeholders, including consumers and employees. A JUST Capital \& Harris Poll (2020) developed in the United States shows that the continuous shift of expectations towards more responsible businesses. The public considers that the COVID-19 pandemic sets a good context for resetting the relationships between corporations and their stakeholders, even more, it is a good moment to reset capitalism - ,a more evolved form of capitalism” being considered, which would work in favor of the average persons, as well as for the next generations. In other words, the public expects corporations to support the sustainable development of society at large.

The reset is needed considering the public view that the pandemic exposed structural problems, made people more aware of them (JUST Capital \& Harris Poll, 2020). During the pandemic, the main stakeholders to be considered have been the employees. Possibly they will retain their relevance after the pandemic, but other stakeholder segments will (re)gain momentum. Overall, considering stakeholders is good business, responsible organizations present a higher return on equity (Mahoney \& Bixby, 2020).

Not only the public / stakeholders expect for responsible organizations. Evidence from business also directs on this path. On the one hand, the previous business and academic studies are supporting the positive impact of being responsible (such as the mentioned JUST Capital study presented by Mahoney \& Bixby, 2020, as well as older investigations such as Wang et al., 2016; Zbuchea, 2013; Zbuchea \& Pinzaru, 2017). On the other hand, business leaders present testimonials on the power of purpose-driven businesses during this turbulent period (Barbato, 2020; Brewster, 2020; Unger, 2020). These are evidence of the need for changing business models and operations. Having in mind knowledge flows and business intelligence might be central to this process.

Overall, there is a positive feeling about the post-pandemic world. Experience of worldwide crises shows increased innovation and creativity, better regulations, and increased social justice (Rynhart, 2020). Other positive dimensions to be considered are more organizational and individual responsibility, as well as greener operations (Lieuw-Kie-Song \& Pérez-Cirera, 2020). 


\section{INTEGRATING THE COVID-19 LESSONS LEARNED INTO KNOWLEDGE MANAGEMENT STRATEGIES AND PLANS}

\subsection{Knowledge management strategies}

Intensively and largely discussed in academia, knowledge management is still a practice to be developed at strategic levels by many organizations despite the generic approval of its utility. The importance of explicit knowledge management approaches in practice is a constant discussion in the international managerial environment, as the imperative of innovation has become the norm for companies' survival and / or expansion in the last two decades. A particularly important factor favouring the development of the KM discussions has been, undoubtedly, the exponential growth of ICT, which has made simpler the access to information, the knowledge capture, share, and analysis. There are several reasons for adopting knowledge management practices, even in the absence of defined strategies assumed and formalized by managers, such as (OECD/Statistics Canada, 2004):

a) to accelerate and improve knowledge transfer to new workers;

b) following merger or acquisition;

c) to ensure knowledge access to all international sites of multinational organizations;

d) to improve the capture of knowledge from exterior sources of the organizations;

e) to protect the organisation from loss of knowledge due to workers' departure;

f) to identify and/or to protect strategic knowledge present in the organisation;

g) to capture workers' undocumented knowledge (know-how);

h) to ease collaborative work of projects or teams that are remote;

i) to improve sharing or transferring of knowledge with partners in strategic alliances;

j) to avoid information overload problems within the organisation;

k) to help managers to focus their attention to key information;

1) to train workers for specific reasons;

$\mathrm{m})$ to encourage managers to share knowledge as a tool for professional promotion of their subordinates;

n) to increase workers' acceptance of innovations / change management strategies and plans;

o) to update the organisation on KM tools or practices used by competitors;

p) to capture and / or share knowledge from / with customers.

In the light of the ICT development, KM practices are subject to an unprecedented development, as a direct result of the more facile access to technology as well as its disruptive influence on organisations passing from rigid structures and processes to fluid ones. As noted by Laihonen \& Huhtamäki (2020), "organisational fluidity refers to the increasing importance of flexibility and dynamics and decreasing importance of organisational boundaries, structures, processes" visible mainly through "the increased autonomy of individuals" (idem). In such contexts, KM should become more than a set of practices, efficient knowledge strategies needing to be open, dynamic, and considering both organizational objectives, collaborative interfaces, and open data. An important factor in promoting KM systems from tacit tactics to explicit strategies remains, however, the support of the top management through transformational leadership (Novak et al., 2020) - an aspect even more desirable in the case of future organizational learning of the Covid-19 pandemic's lessons. As shown by Hsieh et al. (2020), KM strategies after the Covid-19 pandemic will depend not only on a rigorous collecting of the information about the lessons learned, but also on the usage of an appropriate prediction framework to examine potential implementation.

\subsection{Integrating the Covid-19 pandemic's lessons into KM strategies of businesses}

Knowledge management is the third most important aspect perceived by Human Resources managers and talents worldwide after well-being and belonging when asked about their organizational preparedness for the future, mainly in the context of the growing usage of machines at work: "75\% of surveyed organizations say creating and preserving knowledge across evolving 
workforces is important or very important for their success over the next 12-18 months, but only $9 \%$ say they are very ready to address this trend" (Deloitte, 2020, p. 63). The new ways of working catalysed by technology and the physical distance required by authorities in order to contain the Covid-19 virus make the knowledge management need even more urgent. However, there are barriers in implementing at, such as various organizational silos, lack of incentives, lack of technology structure, frequent shifting of which people are in what roles at what time and compliance headwinds (Deloitte, 2020, p. 67).

In order for businesses to integrate the lessons learned after the Covid-19 pandemic and mentioned above into functional knowledge management strategies, a comprehensive framework is needed in order to capture and organize tacit knowledge into explicit one that is put in place. Such an approach is possible as a direct consequence of the current accessibility of technology through various digital solutions and is mandatory for companies trying to learn how to pass from postpandemic survival to agile resilience and reorganization and it could rely on a structure constructed on four major components of KM (figure 1): a) collecting information and organizing a repository of knowledge on b) a collaboration platform that enables c) communication and networking in order to d) create a real culture of knowledge.

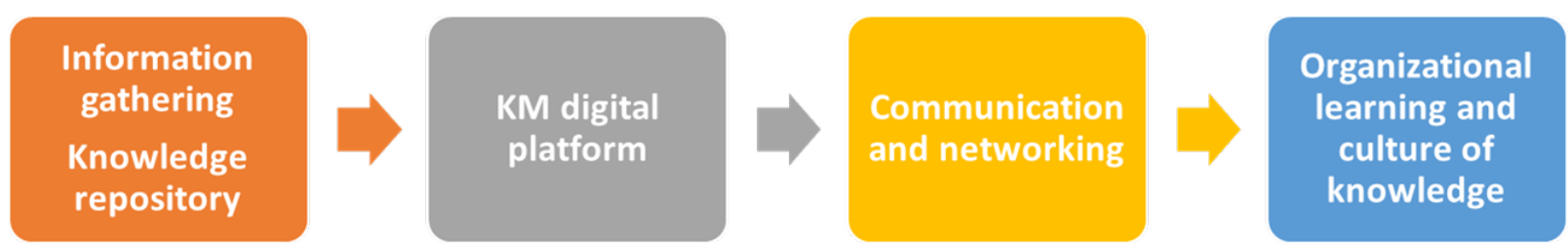

Figure 1. Main elements of knowledge management for Covid-19 pandemic's learned lessons

Source: authors

In our opinion, such an endeavour could be accomplished as follows (points $\mathrm{a}, \mathrm{b}$ and $\mathrm{c}$ below are to be defined only if $\mathrm{KM}$ is not already a strategic line of action in the organization):

a) declaring by the top management the knowledge management as a key element of the overall managerial strategy;

b) including $\mathrm{KM}$ as a distinct part of the managerial strategy and of the annual plans of actions;

c) allocating KM roles to specific employees and/or managers;

d) creating a distinct Covid-19 pandemic learned lessons platform (or a dedicated section into existing KM platform if it is the case). The lessons learned should be clearly marked where they match functionally (i.e. departments, situations, etc.), even if they can be first categorized in generic dimensions as the ones mentioned above. Correct coding and allocation to the right people is a pre-condition as mentioned by previous research (Mohapatra et al., 2016). Userfriendly design of the platform should also be mandatory in order to make the usage as comfortable as possible;

e) disseminating the importance and the usefulness of the new constructed database constantly in cascade to managers and employees through internal communication actions;

f) defining who is in charge for completing and updating data in the platform (roles and access levels);

g) defining who is in charge for promoting the usage of the platform internally;

h) creating organizational incentives for the completion, update, and usage of the information accessible in the platform;

i) defining various levels of access to the knowledge from the platform according to management levels and to roles in the enterprise;

j) building future response capacity based on the Covid-19 pandemic's learned lessons and continuously communicating them as based on these lessons learned; 
k) finally, creating and developing a knowledge culture at both organizational and cultural levels starting from the lessons learned.

The limitations of the above proposed solution, beyond the methodological ones (as it is a not tested empirical proposal), derive from the fact that it doesn't integrate concretely the ineffable knowledge acquired on organizational cultures' shifts and relationships with stakeholders, even if they are real as we've seen above. Moreover, some concrete practical information on concrete solutions on how to reduce costs effectively while modelling scenarios that have not existed before could be understood either as simplistic or as too theoretical. Nevertheless, business ecosystems are expected to be transformed after the pandemics and expectations for more responsible organizations are favoured by the pandemic reality - therefore, adequate knowledge is a must.

\section{CONCLUSIONS}

As in the case of any transformative event that happens at a large scale, hopes are also in the case of the Covid-19 pandemic that at its end, things will go back to the old normal. However, considering the amplitude of the pandemic and the simultaneous existence of technologies that enable collaborations and algorithms at an unprecedent scale, some of the current disruptive changes in the way people work and businesses are managed are to be considered for the future. Knowledge accumulation, integration, and reconfiguration are generic elements to be integrated in every business strategy, but they tend to become even more important after such a challenging test as the one of a pandemic with direct effects on markets, consumers and employees.

For the very first time in the last decades, managers are confronted to the immediate need to integrate "nice to know" concepts as the one of knowledge management into everyday practices and long-term thinking. Our paper is evidence and literature based, and it should be seen more like a manifesto for the integration of $\mathrm{KM}$ into managerial strategic thinking and operational acting starting with the lessons learned from the Covid-19 pandemic. Platforms, algorithms, digital collaborative solutions are here to stay and the current pandemic has created the ideal framework for putting them to work in order to enhance knowledge collecting, sharing and internalizing: in such times, KM is needed more for survival than for development, therefore it is sensed as urgent. Once integrated into strategy and practices, it will become a source for innovation and development. Finally, future research should go beyond empirical discussions towards surveys on the actual implementation of the lessons learned after the Covid-19 pandemic into business strategies.

\section{REFERENCES}

Accenture (2020). COVID-19: New habits are here to stay for retail consumers. August 12. Retrieved from https://www.accenture.com/ro-en/insights/retail/coronavirus-consumerhabits.

Barbato, D. (2020). The Power of Purpose \& Why CEOs are Buying In. Perspectives Blogs. Retrieved from https://perspectives.se.com/blog-stream/the-power-of-purpose-why-ceosare-buying-in.

Bartsch, S., Weber, E., Büttgen, M., \& Huber, A. (2020). Leadership matters in crisis-induced digital transformation: how to lead service employees effectively during the COVID-19 pandemic. Journal of Service Management, ahead-of-print. https://doi.org/10.1108/JOSM05-2020-0160

Berman, S.L., \& Johnson-Cramer, M.E. (2019). Stakeholder theory: Seeing the field through the forest. Business \& Society, 58(7), 1358-1375. https://doi.org/10.1177/0007650316680039

Brewster, D. (2020). Purpose-Driven Leadership During a Crisis. CECP, April 1. Retrieved from https://cecp.co/purpose-driven-leadership-during-a-crisis/. 
Brynjolfsson, E., Horton, J. J., Ozimek, A., Rock, D., Sharma, G., \& TuYe, H. Y. (2020). COVID19 and remote work: an early look at US data (No. w27344). National Bureau of Economic Research.

Chesbrough, H. (2020). To recover faster from Covid-19, open up: Managerial implications from an open innovation perspective. Industrial Marketing Management.

Chinn, D., Klier, J., Stern, S., \& Tesfu, S. (2020). Safeguarding Europe's livelihoods: Mitigating the employment impact of COVID-19. McKinsey \& Company, April, 20.

Choi, T. M. (2020). Innovative "bring-service-near-your-home" operations under Corona-virus (COVID-19/SARS-CoV-2) outbreak: Can logistics become the messiah?. Transportation Research Part E: Logistics and Transportation Review, 140, 101961.

Deloitte (2020). 2020 Global Human Capital Trends Report. Available at https:/www2.deloitte.com/content/dam/Deloitte/cn/Documents/human-capital/deloitte-cnhc-trend-2020-en-200519.pdf.

Diebner, R., Silliman, E., Ungerman, K., \& Vancauwenberghe, M. (2020). Adapting customer experience in the time of coronavirus. McKinsey \& Company, April 2. Retrieved from https:/www.mckinsey.com/business-functions/marketing-and-sales/our-insights/adaptingcustomer-experience-in-the-time-of-coronavirus.

Fana, M., Pérez, S.T., \& Fernández-Macías, E. (2020). Employment impact of Covid-19 crisis: from short term effects to long terms prospects. Journal of Industrial and Business Economics, 47(3), 391-410. https://doi.org/10.1007/s40812-020-00168-5

Finn, P., Mysore, M., \& Usher, O. (2020). When nothing is normal: Managing in extreme uncertainty. McKinsey \& Company. November 2, Retrieved from https://www.mckinsey.com/business-functions/risk/our-insights/when-nothing-is-normalmanaging-in-extreme-uncertainty?cid=other-eml-alt-mip-mck\&hdpid=945e4631-e58b4382-b32b-

b65f36c77939\&hctky=10345468\&hlkid=b77ca6c108474c89821a727bd1e1d181.

Freeman, R.E (1984). Strategic Management: A stakeholder Approach. Boston, MA: Pitman.

Fuciu, M. (2020). Changes in the Organization's Marketing Activity in Light of the Sars-Cov-2 Pandemic. Revista Economica, 72(2). Retrieved from http://economice.ulbsibiu.ro/revista.economica/archive/72203fuciu.pdf.

Gupta, S., Nguyen, T. D., Rojas, F. L., Raman, S., Lee, B., Bento, A., \& Wing, C. (2020). Tracking public and private response to the covid-19 epidemic: Evidence from state and local government actions (No. w27027). National Bureau of Economic Research.

Heinonen, K. \& Strandvik, T. (2020). Reframing service innovation: COVID-19 as a catalyst for imposed service innovation. Journal of Service Management, ahead-of-print. https://doi.org/10.1108/JOSM-05-2020-0161.

Hsieh, H. C., Nguyen, X. H., Wang, T. C., \& Lee, J. Y. (2020). Prediction of Knowledge Management for Success of Franchise Hospitality in a Post-Pandemic Economy. Sustainability, 12(20), 8755.

Hunt, V., Simpson, B., \& Yamada, Y. (2020). The case for stakeholder capitalism. McKinsey \& Company, November. Retrieved November 12, 2020, from https://www.mckinsey.com/ /media/McKinsey/Industries/Public\%20and\%20Social\%20Sect or/Our\%20Insights/The $\% 20$ case $\% 20$ for $\% 20$ stakeholder $\% 20$ capitalism/The-case-forstakeholder-capitalism.pdf?shouldIndex $=$ false.

ILO (2020a). ILO Monitor: COVID-19 and the world of work. Third edition. ILO, April 29. Retrieved from https://www.ilo.org/wcmsp5/groups/public/---dgreports/--dcomm/documents/briefingnote/wcms_743146.pdf.

ILO (2020b). Slow COVID-19 labour market recovery expected in Latin America and the Caribbean. November 10. Retrieved from https://www.ilo.org/global/about-theilo/newsroom/news/WCMS_760607/lang--en/index.htm. 
Jaeggi, R. (2016). What (if anything) is wrong with capitalism? Dysfunctionality, exploitation and alienation: three approaches to the critique of capitalism. The Southern Journal of Philosophy, 54, 44-65.

Jappe, A. (2017). The writing on the wall: On the decomposition of capitalism and its critics. John Hunt Publishing.

Jonasson, P., Board, E., Clemens, R., van der Wilden, E., \& Voorspuij, J. (2020). Sustainable postCOVID-19 supply chain recovery through global data standards. Report. Retrieved October 12, 2020, from https://www.unescap.org/sites/default/files/113\%20FinalTeam\%20Patrik\%20Jonasson-GS1.pdf.

JUST Capital \& Harris Poll (2020). SURVEY: What Americans Want from Corporate America During the Response, Reopening, and Reset Phases of the Coronavirus Crisis. Retrieved November 12, 2020, from https://justcapital.com/reports/survey-what-americans-want-fromcorporate-america-during-the-response-reopening-and-reset-phases-of-the-coronaviruscrisis/.

KPMG (2020). Operations restructuring for a post-COVID-19 world. Retrieved September 17, 2020, from https://assets.kpmg/content/dam/kpmg/xx/pdf/2020/08/restartingsupplychain.pdf.

Laihonen, H., \& Huhtamäki, J. (2020). Organisational hybridity and fluidity: deriving new strategies for dynamic knowledge management. Knowledge Management Research \& Practice, 1-13.

Lang, B., Dolan, R., Kemper, J., \& Northey, G. (2020). Prosumers in times of crisis: definition, archetypes and implications. Journal of Service Management, ahead-of-print. https://doi.org/10.1108/JOSM-05-2020-0155

Li, X., Wang, B., Liu, C., Freiheit, T., \& Epureanu, B. I. (2020). Intelligent Manufacturing Systems in COVID-19 Pandemic and Beyond: Framework and Impact Assessment. Chinese Journal of Mechanical Engineering, 33(1), 1-5.

Lieuw-Kie-Song, M., \& Pérez-Cirera, V. (2020). A better future of work means building it green. ILO Blog, October 12. Retrieved from https://iloblog.org/2020/10/12/a-better-future-ofwork-means-building-it-green/.

Mahoney, C., \& Bixby, S. (2020). Chart of the Week: JUST Businesses Have a Higher Return on Equity. JUST Capital, October 28. Retrieved November 12, 2020, from https://justcapital.com/news/chart-of-the-week-just-businesses-have-a-higher-return-onequity/.

McKinsey (2020a). Consumer sentiment and behaviour continue to reflect the uncertainty of the COVID-19 crisis. October 26. Retrieved from https://www.mckinsey.com/businessfunctions/marketing-and-sales/our-insights/a-global-view-of-how-consumer-behavior-ischanging-amid-covid-19.

McKinsey (2020b). How COVID-19 has pushed companies over the technology tipping point—and transformed business forever. October 5. Retrieved from https://www.mckinsey.com/business-functions/strategy-and-corporate-finance/ourinsights/how-covid-19-has-pushed-companies-over-the-technology-tipping-point-andtransformed-business-forever.

Mhlanga, D., \& Moloi, T. (2020). COVID-19 and the Digital Transformation of Education: What Are We Learning on 4IR in South Africa?. Education Sciences, 10(7), 180.

Mohapatra, S., Agrawal, A., \& Satpathy, A. (2016). Designing knowledge management strategy. In Designing Knowledge Management-Enabled Business Strategies (pp. 55-88). Springer, Cham.

Mysore, M., \& Usher, O. (2020). Responding to coronavirus: The minimum viable nerve center. McKinsey \& Company, March 16. Retrieved from https://www.mckinsey.com/businessfunctions/risk/our-insights/responding-to-coronavirus-the-minimum-viable-nerve-center. 
Novak, A., Breznik, K., \& Natek, S. (2020). How leaders can initiate knowledge management in organizations: Role of leadership style in building knowledge infrastructure. Human Systems Management, 39(1), 37-50.

OECD/Statistics Canada (2004), Measuring Knowledge Management in the Business Sector: First Steps, Knowledge management, OECD Publishing, Paris.

Papanikolaou, D., \& Schmidt, L. D. (2020). Working Remotely and the Supply-side Impact of COVID-19 (No. w27330). National Bureau of Economic Research.

Pató, B. S. G., \& Herczeg, M. (2020). The Effect of the Covid-19 on the Automotive Supply Chains. Studia Universitatis Babes-Bolyai Oeconomica, 65(2), 1-11.

Paul, S.K., \& Chowdhury, P. (2020). A production recovery plan in manufacturing supply chains for a high-demand item during COVID-19. International Journal of Physical Distribution \& Logistics Management. Ahead-of-print. https://doi.org/10.1108/IJPDLM-04-2020-0127

Pinzaru, F., Zbuchea, A., \& Anghel, L. (2020). The Impact of the COVID-19 Pandemic on Business. A Preliminary Overview. In Bratianu, C., Zbuchea, A., Anghel, F., \& Hrib, B. (2020), Strategica. Preparing for Tomorrow, Today (pp.721-730), Bucharest, RO: Tritonic.

Pouliakas, K., \& Branka, J. (2020). EU Jobs at Highest Risk of COVID-19 Social Distancing: Will the Pandemic Exacerbate Labour Market Divide?. IZA Discussion Paper No. 13281. $\begin{array}{llll}\text { Retrieved June 22, 2020, from } & \text { 22 }\end{array}$ https://papers.ssrn.com/sol3/papers.cfm?abstract_id=3608530.

Prasad, D.K., Rao, M., Vaidya, D.R., \& Muralidhar, B. (2020). Organizational Climate, Opportunities, Challenges and Psychological Wellbeing of the Remote Working Employees during COVID-19 Pandemic: A General Linear Model Approach with Reference to Information Technology Industry in Hyderabad. International Journal of Advanced Research in Engineering and Technology, 11(4).

Priyono, A., Moin, A., \& Putri, V. N. A. O. (2020). Identifying Digital Transformation Paths in the Business Model of SMEs during the COVID-19 Pandemic. Journal of Open Innovation: Technology, Market, and Complexity, 6(4), 104. https://doi.org/10.3390/joitmc6040104

PwC (2020). Evolving priorities: COVID-19 rapidly reshapes consumer behavior. Retrieved from https://www.pwc.com/us/en/industries/consumer-markets/library/covid-19-consumerbehavior-survey.html.

Ratten, V. (2020). Coronavirus (covid-19) and social value co-creation. International Journal of Sociology and Social Policy. Ahead of print. https://doi.org/10.1108/IJSSP-06-2020-0237.

Rothwell, J. (2020). Report. The effects of COVID-19 on international labor markets: An update. May 27. Retrieved from https://www.brookings.edu/research/the-effects-of-covid-19-oninternational-labor-markets-an-update/.

Rynhart, G. (2020). Looking back to look forward: What does the next normal look like? ILO Blog, August 26. Retrieved from https://iloblog.org/2020/08/26/looking-back-to-look-forwardwhat-does-the-next-normal-look-like/.

Sethi, B., \& Brown, P. (2020). Why corporate well-being initiatives need to get personal. Strategy+business, September 18. Retrieved September 25, 2020, from https://www.strategy-business.com/article/Why-corporate-well-being-initiatives-need-toget-personal?gko=b757e.

Shen, H., Fu, M., Pan, H., Yu, Z., \& Chen, Y. (2020). The impact of the COVID-19 pandemic on firm performance. Emerging Markets Finance and Trade, 56(10), 2213-2230.

Shokrani, A., Loukaides, E. G., Elias, E., \& Lunt, A. J. (2020). Exploration of alternative supply chains and distributed manufacturing in response to COVID-19; a case study of medical face shields. Materials \& design, 192, 108749.

Sidibe, M. (2020). Marketing meets mission. Harvard Business Review, 135.

Sneader, K. \& Sternfels, B. (2020). From surviving to thriving: Reimagining the post-COVID-19 return. McKinsey \& Company, May 1. Retrieved June 12, 2020, from 
https://www.mckinsey.com/featured-insights/future-of-work/fromsurviving-to-thrivingreimagining-the-post- COVID-19-return.

Soto-Acosta, P. (2020). COVID-19 Pandemic: Shifting Digital Transformation to a High-Speed Gear. Information Systems Management, 37(4), 260-266. https://doi.org/10.1080/10580530.2020.1814461

Stephens, K.K., et al. (2020). Collective sensemaking around COVID-19: experiences, concerns, and agendas for our rapidly changing organizational lives. Management Communication Quarterly, 34(3), 426-457. https://doi.org/10.1177/0893318920934890

Unger, D. (2020). Diversification and vision drive success in a crisis. Strategy + Business, November 5. Retrieved November 10, 2020, from https://www.strategybusiness.com/article/Diversification-and-vision-drive-success-in-acrisis?gko=427ea\&utm_source $=\mathrm{itw} \& u t m \_$medium $=\mathrm{itw} 20201110 \& u t m \_$campaign $=$resp.

Unruh, G., \& Kiron, D. (2017). Digital transformation on purpose. MIT Sloan Management Review, 6.

Valentinov, V., Roth, S., \& Will, M.G. (2019). Stakeholder theory: A Luhmannian perspective. Administration \& Society, 51(5), 826-849. https://doi.org/10.1177/0095399718789076

Verma, S., \& Gustafsson, A. (2020). Investigating the emerging COVID-19 research trends in the field of business and management: A bibliometric analysis approach. Journal of Business Research, 118, 253-261.

Wang, Q., Dou, J., \& Jia, S. (2016). A meta-analytic review of corporate social responsibility and corporate financial performance: The moderating effect of contextual factors. Business \& Society, 55(8), 1083-1121.

Wang, Y., Hong, A., Li, X., \& Gao, J. (2020). Marketing innovations during a global crisis: A study of China firms' response to COVID-19. Journal of Business Research. 116, 214-220. https://doi.org/10.1016/j.jbusres.2020.05.029.

Williams, C.C., \& Kayaoglu, A. (2020). COVID-19 and undeclared work: impacts and policy responses in Europe. The Service Industries Journal, 40(13-14), 914-931. https://doi.org/10.1080/02642069.2020.1757073.

Yeon, H. (2020). Six capabilities to sustain digital transformations. McKinsey \& Company. Retrieved from https://www.mckinsey.com/about-us/new-at-mckinsey-blog/digitalcapabilities-to-sustain-transformation.

Zbuchea, A. (2013). Are Customers Rewarding Responsible Businesses? An Overview of the Theory and Research in the Field of CSR. Management Dynamics in the Knowledge Economy, 1(3), 367-386.

Zbuchea, A., \& Pînzaru, F. (2017). Tailoring CSR Strategy to Company Size?. Management Dynamics in the Knowledge Economy, 5(3), 415-437. 